\title{
Optimising franchisee sales and business performance
}

Received (in revised form): 17 August 2007

\section{Rajagopal}

is Professor of Marketing at Monterrey Institute of Technology and Higher Education (ITESM), Mexico City Campus, and Fellow of the Royal Society for Encouragement of Arts, Manufacture and Commerce, London. He has been listed with biography in Who's Who in the World, 2007. He holds a doctoral degree from Ravishankar University, India, and has been conferred the membership (level-II) of Mexican National System of Researchers. He teaches various topics of marketing in graduate, doctoral executive development programmes of the Institute. Dr Rajagopal held key positions in many premier management institutes in India including Administrative Staff College of India.

\begin{abstract}
This paper aims at identifying the attributes of players in the franchising process that contribute in delivering satisfaction in purchasing and operating the outlets in Mexico. The discussion also focuses the impact of cultural diversities in franchisee selection, outlet management and achieving high performance. Franchisee relationship has been evaluated in reference to principal determinants attributing to the enhancement of satisfaction and strengthening franchisor-franchisee ties. It has been observed in the study that the performance of franchisee outlets is a function of outlet attraction, supply and manufacturing management, quality, price and promotional strategies as functional factors. Besides, relational variables including personalised customer services, leisure support and customer convenience also influence the performance of outlets.
\end{abstract}

\section{Keywords:}

franchising, performance measurement, market demand, sales management, retailing, customer value

Journal of Retail and Leisure Property (2007) 6, 341-360. doi:10.1057/palgrave.rlp.5100069

\section{Rajagopal}

Monterrey Institute of Technology and Higher Education, ITESM Mexico City Campus 222, Calle del Puente Ejidos de Huipulco, Tlalpan DF 14380 Mexico

Tel: +525554832251

Fax: + 525554832234 E-mail: rajagopal@itesm.mx Web: http://www.geocities.com/ prof_rajagopal/homepage.html

\section{INTRODUCTION}

The practice of franchising is widely experienced by multinational retail food chains particularly in the fast food sector. Franchising is emerging as a highly effective strategy for business growth, local employment and regional economic development. The quest for global markets through franchising has, however, traditionally relied on employing just three generic franchising options including direct franchising, master franchising and area development. ${ }^{1}$ Significantly large per cent of retail sales pass through chains that engage in franchising as many industries are being transformed as chains replace the mom-and-pop proprietors who used to sit on every street corner. Franchising strategy as a tool for 
managing restaurants in North America was initiated in 1930s and in the mid-1940s, Dairy Queen was set -up, followed by McDonald's, Pizza Hut and Kentucky Fried Chicken in the 1950s and 1960s. These firms witnessed a quick expansion of their business through franchising operations. ${ }^{2,3}$ Traditional franchise research suggests that there is a dichotomy in the sources of power available to franchisors, that is, coercive or noncoercive sources of power. Hence, franchise partner selection, the franchise relationship and the use of master/area franchising emerge from the qualitative findings as further control mechanisms available to international retail franchisors. In the selection of franchisees, overseas firms face many cultural problems that require firms to acquire significant knowledge on the social and cultural diversities to choose a retailer. The greater the cultural distance, the more challenges the firm has to face in terms of upgrading and adapting its prior knowledge to local needs. ${ }^{4}$ As international retailers continue to use franchising as a major method of market entry, management and control of these international retail franchise networks becomes of significant importance to measure their business performance. ${ }^{5}$

Franchisee stores, which largely operate in chain, are based on the rationale of touch, feel and pick that provides consumers with a wide range of options to make buying decisions. The in-stores promotions and do it yourself (DIY) opportunities constitute the major motivation for the buyers and also support them in their decision-making process. Motivational forces are commonly accepted to have a key influencing role in the explanation of shopping behaviour. Personal shopping motives, values and perceived shopping alternatives are often considered independent inputs into a choice model; it is argued that shopping motives influence the perception of retail store attributes as well as the attitude towards retail stores. ${ }^{6}$ Although consumer exercises limited brand options in a franchisee store, both service and merchandise quality exert a significant influence on store performance and may be measured by sales growth and customer growth, and their impact is mediated by customer satisfaction. Thus, franchisee stores offer an environment of three distinct dimensions of emotions, for example, pleasantness, arousal and dominance to augment the customer value and the performance of the store. ${ }^{7}$ In franchisee stores, customer satisfaction is a key to brand growth, while the positive effect of customer satisfaction on brand revenue performance is moderated by the extent of franchising within each brand.

Despite business convenience for the overseas firms and economic importance of franchising to the region, not enough contributions were made to evaluate the factors influencing franchisee value, generating store attractiveness, customer satisfaction and services quality through empirical investigation. This paper aims at identifying attributes of players in franchising process that contribute in delivering satisfaction in the purchasing and operating the outlets in Mexico. The discussion also focuses on the impact of cultural diversities in franchisee selection, outlet management and achieving high performance. Franchisee relationship has been evaluated in reference to principal determinants attributing to the enhancement of satisfaction and strengthening franchisor-franchisee ties. 


\section{REVIEW OF LITERATURE}

\section{Franchise administration}

Multinational retails chains have successfully adopted franchising as an expansion tool in overseas markets after examining its advantages. The advantages of franchising comprise allowing the firm to overcome resource constraints of limited capital and thin the ranks of experienced managers. Franchising also provides a means of trading off complex transfer functions and franchisees are more efficient in performing functions whose average cost curve turns up relatively quickly. It obviates the need for monitoring and its attendant costs because franchisees have invested their own capital and is motivated to work hard for profitability. ${ }^{8}$ The franchise contract, support mechanisms, franchise partner selection, the franchise relationship and the use of master/area franchising were found to be the major methods by which international retail franchisors exert control over their franchise networks. While coercive and noncoercive sources of power were identified in the form of the franchise contract and support mechanisms, the paper also identifies sources of relationship power and organisational power. ${ }^{5}$ Although franchisors value the benefits of the mix of ownership types and do maintain that mix over time, there is some evidence of a greater tendency to permanently convert existing franchised outlets to companyowned outlets as fast food systems mature and gain greater access to resources. ${ }^{9}$ Franchising offers substantial efficiencies in promotion and advertising by leveraging the value of a trademark and brand image. Moreover, it helps in managing one's risks, because franchisors can eventually convert profitable franchise locations into company-owned operations, although this strategy raises certain ethical concerns.

Globalisation has moved the multi-brand concepts and co-branding in franchising as a strategy to stimulate and rejuvenate growth in a mature retail food franchising sector. Development trends such as multiple unit franchising, mobile franchising and co-branding occur because of the sector's need to find new means of expansion beyond the standard model of franchising. ${ }^{10}$

New approaches are emerging in franchise administration towards streamlining customer centric franchise system, and it may be necessary to understand how and when to deploy different knowledge management components. ${ }^{11}$ The zone-of-tolerance (ZOT) is an innovative concept that has attracted recent attention in the services marketing domain. The ZOT represents a range of service performance that a customer considers satisfactory, which recognises multiple expectation standards, and specifically adequate and desired expectations. A moderating role for the ZOT in the quality-key outcomes relationship implies that to maximise investments in service improvements, there should be a focus on increasing service quality beyond the adequate level, rather than seeking to develop a customer franchise by creating 'delight'. ${ }^{12}$ Franchising is primarily seen as a foreign concept in emerging markets that attracts both positive and negative attention. Franchisees evaluate such business negotiation with reference to the wellbeing of small businesses, socioeconomic, socio-cultural wellbeing and employment opportunity as major 
decision factors. Some of these factors were associated with patronage behaviour and the associated residual feeling. ${ }^{13}$

Franchisors of food products need to see the market situation and end customer demand in order to efficiently allocate production capacity and procure materials; however, the difficulty in obtaining timely and accurate demand data from the point-of-sales (POS) calls for alternative solutions to be developed. A research study offers a solution that is based on readily available sell-through data from channel partners, such as distributors, to monitor what happens on the market in product introduction situations. The difficulty with using demand information from distributors rather than the POS is the bullwhip effect that distorts demand as the firm moves upstream in the supply chain. ${ }^{14}$ Physical factors such as time and place involved in buying new products also affect the consumer decisions to new products. Besides, the perceived use value of technology-based products influences consumers' evaluations of the franchisees. ${ }^{15}$

\section{Franchising and customer value}

It has been observed that franchisees often do not recognise that what influences customer satisfaction is not the same as what engenders store loyalty, and consequently do not allocate scarce resources systematically among tactics influencing one or the other. Unless they are vigilant to changing consumer behaviour patterns, they will not be able to isolate in their strategy the elements of the retail mix that could insulate their loyal customers from responding to competitors' special offers. ${ }^{16}$ Another study confirms that there exist significant differences in consumer perceptions of hedonic shopping value across several retail brands. Therefore, customers appear to recognise the uniqueness among the in-store experience that retailers are working hard to achieve. This delivery of value, then, seems to be an effective source of differentiation. The results of this study indicate that retailers using a 'store as the brand' strategy should continue to invest in creating a specific, unique shopping experience for their target customer. Retailers, however, should always be mindful that regardless of the excitement and fun delivered in the shopping experience, consumers appear to expect utility including the right merchandise, in the right place, at the right time and at the right price. ${ }^{17}$ The growth of franchising is regarded as having significant implications for development of retailing. Shopping behaviour at franchisee outlets prompts a sequential relationship among tourists leading to shopping satisfaction through the perceived values on recreational attractions and store loyalty. Thus, managers may think of significant franchisee expansion on a demographic and territorial basis for enhancing the loyalty in shopping behaviour. Franchising in a sub-urban marketplace is a relatively recent phenomenon that demands new retail infrastructures and recreational facilities to attract leisure shopping. The customer satisfaction has become one of the measures of retailing performance. Leisure eating behaviour in restaurants and buying souvenirs, fashion products and high-value products indicate that the retailing strategy is becoming more customer-centric at franchisee outlets. $^{18}$ 
The customer value concept is utilised to assess product performance and to determine the competitive structure of the new products. The analytical approach to the franchisee-based retailing structure based on customer value may be fitted well within the microeconomic framework. The measure of customer value as the product efficiency may be viewed from the customer's perspective towards a ratio of outputs (eg, perceived use value, resale value, reliability, safety, comfort) that customers obtain from a product relative to inputs (price, running costs) that customers have to deliver in exchange. The efficiency value derived can be understood as the return on the franchisees investment. Franchisee stores offering a maximum customer value relative to all other alternatives in the market are characterised as efficient. Different efficient products may create value in different ways using different strategies (output-input combinations). Each efficient product can be viewed as a benchmark for a distinct sub-market. Jointly, these products form the efficient frontier, which serves as a reference function for the inefficient products. ${ }^{19}$ In the most optimistic settings, such value measures are observed to be generated by franchisor firms for new franchisees in view of augmenting the business-to-business relationship and market expansion strategies of the firm. The fast-moving food sector has a quick shelf turnover at a relatively low cost and quick buying decisions of consumers. The rate of change within this market sector continues apace, particularly in the areas of innovation and value addition to the customers. A firm may combine innovation and technologies in the franchising strategy to create business value and competitive gains. New and modern franchisees have moved rapidly into the growing fast-moving consumer goods retail market. The fast food retailing sector is largely attracted by the innovations in product attributes and packaging besides the price sensitivity. It has been observed that the effects of the franchising decisions of foreign firms are systematically moderated by elements of the marketing strategy associated with the innovative retailing and customer relationship competencies of franchisee firms. ${ }^{20}$

\section{Performance measures in franchising}

The success of franchising also depends on the compensation arrangements followed in the franchise relationship. Consistent with predictions suggested by agency theory, the compensation arrangements studied appear to function as substitutes. It has been observed that the value of the services provided by franchisors to franchisees strongly affects the compensation arrangements studied, and so a capital goal of these arrangements is to recover the costs of the services offered by franchisors. ${ }^{21}$ In addition, two dimensions of transactional quality are identified from the franchisee perspective that includes contents and assistance. On the other hand, these dimensions of transactional quality from the franchisor's point of view refer to formality and identify business opportunities while the relationship quality identifies variables such as trust between cooperation partners, mutual commitment and relational sensitivity. The franchise system has assumed great importance as a pattern for the expansion of services and, just like any other 
organisation, needs to preserve the quality of the business concept to achieve overall success. ${ }^{22}$

The success of franchise systems is usually explained by referring to franchisees' incentives, that is, residual claims to profit and empowerment through delegation. Of many human factors, psychological and social dimensions of franchisees' incentives, employed managers' self-efficacy, system commitment and system conformity performance play distinct roles in driving the franchisee outlets to success and sustaining competitive pressures. Franchising has met or exceeded the growth expectations, generating very high annual sales in the developing countries. Considerable regional differences in franchising activities do exist however. The business sectors experiencing the most franchising growth are retail and restaurants. Franchising firms tend to export their business formats to neighbouring countries or to countries with similar cultural characteristics. ${ }^{23}$ As franchisees are perceived to be independent and self-employed entrepreneurs, their ongoing development is frequently overlooked or poorly managed, particularly compared with the development opportunities for corporate staff in their support offices. The concern, however, is that franchisees do not prioritise their own professional development due to their inability to diagnose and source appropriate training, their focus on immediate operational needs and a lack of free time to undergo development activities. As primary income generators of franchise businesses, organisational effectiveness and growth of the entire organisation rests on the abilities of the franchisees. ${ }^{24}$

The differences in the learning and thinking patterns influence how people process information, as demonstrated in their natural responses to business communications. The SMART variables may be considered to manage the process of franchisee selection and motivation towards optimising their performance. The SMART variables include strategy orientation, measurability, approach, reality and time frame. The strategy orientation would drive the brainstorming discussion to result orientation and the measurability would count on the success of the deliberations. ${ }^{25}$ The facts of information, endorsed commitments (contracts), pilot observation on the committed tasks, previous track records of the people getting associated in the business from the low-trust regions, setting legal implication and the like may be appropriate strategies to conduct business with the people of low-trust countries. Development of trust, however, can best be carved by a balanced and coordinated set of activities designed to enhance both cognitive and behavioural aspects. ${ }^{26}$

\section{THEORETICAL CONSTRUCT}

The franchisee performance in the retail food sector is largely associated with the franchisee outlets brands and customer services offered therein. Franchisee outlet preferences among customers are the basic discrete time that helps the customers in making a buying decision and maximising the value of product and services. The value of product and service is not always the same in the franchisee outlets and is subject to value lifecycle that governs the customer preferences in the long run. ${ }^{27}$ If customers prefer the product and service for $N$ periods with $Q$ as franchisee 
satisfaction perceived by the customer, the value may be determined as $Q>N$, where both $Q$ and $N$ are exogenous variables. If every customer receives higher perceived values for each of his buying, the value added to product may be $q \geqslant Q$, where ' $q$ ' refers to the change in the quality of goods and services provided at the franchisee outlets by innovation or up-graded technology. The customer may refrain from buying the products if $q \leqslant Q$, which does not influence his buying decisions. A strong referral $(\overline{\mathrm{R}})$, however, may lead to influence the customer values, with an advantage factor $\beta$ that may be explained by price or quality factor. In view of the above discussion, it may be assumed that customer preferences have a high variability that affects retail buyers' decisions:

$P_{f n}=\sum_{t=1}^{N} \beta^{t}\left(C_{t}, \hat{Z}, F_{x}\right)+\bar{R}\left(\beta^{N+1} Q_{t}\right)$

where $\left(P_{f n}\right)$ is expressed as the performance of the franchisee outlet, $C_{t}$ represents consumption, $\hat{Z}$ is a vector of franchisee attributes (viz. personalised customer relations, leisure support and customer convenience), $(\mu)$ is the coefficient of promotional expenditure used by the franchisee, $\left(F_{x}\right)$ is the measure of the franchisor-franchisee relationship in managing business and $Q_{t}$ is the value perceived by the customer. The performance of the franchisee depends on various tangible and intangible factors to be concerning major marketing and selling functions. The value equation for performance of franchisee outlets may be expressed as a function of all value drivers wherein each driver contains the parameters that directly or indirectly offer competitive advantages to the customers and enhance the business relationship with the franchisor.

$V^{\prime}=K_{s}, K_{m}, K_{d}, K_{c}\left[\prod\{\hat{Z}(x, t, q, p)\}\right]$

In the above equation, $V^{\prime}$ is a specific performance driver, $K$ are constants for supplies $\left(K_{s}\right)$, margins $\left(K_{m}\right)$, distribution $\left(K_{d}\right)$ and cost to customers $\left(K_{c}\right) ; x$ is the volume, $t$ is the time, $q$ is the quality and $p$ denotes the price. The franchisee attribute $(\hat{Z})$ is a function of price $(p)$ and nonprice factors including quality $(q)$ and volume $(x)$ in a given time $t$. Accordingly, $\Pi$ has been used as a multiplication operator in the above equation. The quality of the product, customer services and volume of sales are closely associated with the performance of franchisee outlets. The total utility for the highly attractive franchisee outlets goes up due to economy of scale as the quality is also increased simultaneously $\left(\partial_{v} / \partial_{x}>0\right)$. The $\partial_{v}$ franchisee value is enhanced by offering larger volume of sales at a competitive price in a given time $\left(\partial_{v} / \partial_{p}>0\right)$ and $\left(\partial_{v} / \partial_{t}>0\right)$. Conventional franchisee outlets create lower sales and customer value $\left(\partial_{v} / \partial_{x}<0\right)$ while the modern outlets offer products irrespective of price advantages, and enhance the customer value $\left(\partial_{v} / \partial_{x}>0\right)$. Modern franchisee outlets in the food sector offer in-store recreational facilities and leisure services to add value to the customers. Accordingly, conventional franchisee outlets provide lesser scope for business enhancement and customer satisfaction as compared to the modern franchisee outlets. 
Let us assume that $\left(x_{0}, x_{1}, x_{2} \ldots x_{n-1}, x_{n}\right)$ represents factors of franchisee performance at different stages of product attractiveness, increasing with reference to the derived advantage from the competing product and outlets in a given market at a given time $(t)$. In the process of enhancing the franchisee performance for the outlets, a firm may use improved retailing technology, high product quality, competitive pricing, high competency in managing the $\mathrm{P}$-factors comprising the product, price, place, promotion, packaging, pace, people, performance, psychodynamics, posture and proliferation of the firm. Besides, a franchising firm should also derive intensive customer relationship management (CRM) strategies simultaneously to the competitive sales and marketing strategies. The integrated impact of CRM, sales and marketing strategies at different stages of product attractiveness would contribute to the customer value. Accordingly, an aggregated franchisee demand represented by $X_{n}$ can be calculated with the following operation:

$\left(X_{n}\right)=f\left(x_{0}\right) \Delta x+f\left(x_{1}\right) \Delta x+f\left(x_{2}\right) \Delta x+\ldots+f\left(x_{n-1}\right) \Delta x$

On further simplifying this equation, we obtain

$A\left(X_{n}\right)=\left(X_{n}\right)_{\lim n \rightarrow \infty}+\sum_{k m}^{j m}\left[\left(\Delta v^{\prime}+\Delta b^{\prime}\right)(\Delta s)\right]^{t}+Z_{x i}$

In the above equation, $A\left(X_{n}\right)$ represents the aggregate demand of the outlets derived at various stages of outlet attractiveness and quantitative changes in the volume of goods positioned by the firm and $\left(Z_{x i}\right)$ represents the customer services offered by the franchisees that help in inducing repeat buying, and market coverage in terms of changes in the market shares of the firms. Thus, aggregate performance may be measured by a firm for not only the existing market locations but also for the potential markets $A\left(X_{n}\right)_{\lim n \rightarrow \infty}$. The number of customers attracted by the franchisee promotion, influence of referrals and augmented perceived use values derived by the customers may be the major factors contributing in determining the potential markets for the franchisees. ${ }^{28} \mathrm{~A}$ franchising firm, however, may identify the potential markets in reference to its competitive strengths and opportunities. Besides, a firm may need to compute the trend of market demand for all the products in its product line, and measure the variability in the customer values perceived for its products. The customer value trend for a given product line $\left(p_{t}\right)$ may be derived through the following equation:

$V_{p_{l}}^{t_{0}-\infty}=\sum_{k n}^{j m}[A(\bar{R}+\hat{Z})] \frac{\partial s}{\partial t}$

In the above equation, the performance of franchisee outlets may be measured across the time frame $V^{\left(t_{0}-\infty\right)}$, which represents the spread of performance from the time of introduction of the outlet $\left(t_{0}\right)$ till the projected period $\left(t^{\infty}\right)$. The performance of the franchisee outlet will be enhanced as demand rise $(\partial s / \partial t \geqslant 0)$ with positive word of mouth and customer-centric attributes of franchisees in time $t$. It may be possible that a franchising firm may acquire a higher market share but performance in reference to the products within the given product line may be relatively 
lower. Under such conditions, the profit contributed by the franchising firm may be described as

$Y_{t}=f\left[\hat{Z}, V^{\prime}, X_{n}\right] \frac{\partial s}{\partial t}=P_{f n} \geq 0$

wherein $Y_{t}$ represents the profit realisation by the franchisee outlet in time $t$. Data on the above variables are adjusted to the seasonality pattern of the products for selected food products categories using a fixed 4-week time lag of each explanatory variable and included in the regressions. Specifically, the following equation is estimated using ordinary least squares (OLS) deriving from equation (6):

$$
\begin{aligned}
P_{f n}= & \alpha+\beta_{1}\left(P f_{t i}^{j}\right)+\beta_{2}\left(P f_{(t-1)_{i}}^{j}\right)+\beta_{3}\left(P f_{t i}^{m}\right)+\beta_{4}\left(P f_{(t-1)_{i}}^{m}\right) \\
& +\beta_{5}\left(N p s_{t i}^{j}\right)+\beta_{6}\left(S n p_{t i}^{m}\right)+\beta_{7}\left(Y_{t}\right)+\varepsilon_{t i \ldots n}
\end{aligned}
$$

The performance of franchisee outlets has been estimated in reference to the product line $\left(P f_{t i}^{j}\right)$, which has been considered as a proxy to market demand, overall outlet attractiveness in reference to price and promotion packages $\left(P f_{t i}^{m}\right)$ in the market as a proxy to aggregate demand, volume of sales in the outlets $\left(N p s_{i t}^{j}\right)$ and seasonality in sales at franchisee outlets $\left(S n p_{i}^{m}\right)$ in the given market $m$.

The model explains that the high-performance franchisee outlets would enhance the business expansion opportunities and customer value as the efficiency of franchising firm is viewed as a ratio of outputs (eg volume of sale, economy of scale, competitive gains, leadership, safety, profit) that the customers obtain from a product relative to inputs (quality, price and satisfaction). The derived efficiency of franchisee outlets can be understood as the return on the investment. If the attributes of franchisee performance are low, the forward (with customers) and backward relationship (with the franchisor company) may be risk averse and the franchisee outlets may face hardship to sustain competition.

\section{STUDY DESIGN}

\section{Hypotheses}

There are various factors including aspects of franchisee agreement, locations, logistics, inventory strategy, pricing, promotion, salespeople, alliances with external service and support organisations, and the effect on profit and competitive brand profile in the marketplace. Pricing is one of the major factors that affects the performance of franchisee outlets at a given time and market as it stimulates the demand upwards or negatively. ${ }^{29}$ Fluctuations in demand are attributed to diverse factors mainly competitive conditions, customer preferences, sales and supply systems. Hence, the hypothesis may be framed as

H1: The demand for franchisee outlets is more responsive to the market conditions than projected aggregate demand.

It has been observed that seasonality in a franchisee outlet is reflected in one of the three main strategy manifestations as diversification of the 
product mix, change of the customer mix and aggressive pricing. Franchisee firms often sell their products only for a limited time. This phenomenon can be interpreted as the firms' strategy to increase their profits by prohibiting consumers from learning their personal values of the product as time passes. Such an explanation can also be used to explain the firms' strategy to set low prices on their new products for only a limited time..$^{30}$ Niche marketing is an alternate and effective strategy for countering price competition in a mature industry and can use a niche market strategy. Among the many key success factors, the most important was found to be a thorough understanding of the targeted consumers. It is concluded that the marketing mix plays a more important role than is generally suggested in the literature, by communicating nonprice product attributes to the niche market. ${ }^{31}$ Therefore, the hypothesis may be constructed as below:

H2: Franchising business operation is sensitive to the market demand, business cycle and seasonality factor.

The introduction of new marketing and sales technologies in the franchisee outlets makes it important for marketers to understand how innovators or first adopters respond to persuasion cues. It has been observed in a study that the innovativeness and perceived newness in consumption at the franchisee outlets, which are one of the constituents of outlet attractiveness, are independent constructs that had independent effects on customer's attitude towards the brand and purchase intent for the new product. ${ }^{32}$

Organisational values and customer relationship approaches of the company also influence the customers to acquire higher values. The performance of franchisees may create value in different ways using different strategies (output-input combinations). Each franchisee outlet can be viewed as a benchmark for a distinct sub-market. ${ }^{19}$ Besides, the attractiveness of franchisee outlets is one of the key factors affecting the decision making of customers and in turn is related to market growth and sales. The higher the positive reactions of the customers towards the new products in view of their attractiveness, the higher the growth in sales and so in market. ${ }^{33}$ It may also be stated that higher price volatility makes consumers more sensitive to gains and less sensitive to losses, while intense price promotion by competing brands makes consumers more sensitive to losses but does not influence consumers' sensitivity to gains. ${ }^{34}$ Accordingly, hypotheses may be framed as

H3: The attractiveness of franchisee outlets in reference to brand value, quality of the product, competitive advantages and price along with other relational variables determines the level of performance of the outlet and associated customer value.

The factors associated with the customer value in reference to brand value, pricing and competitive advantages have been envisaged in 
equations (4)-(6) derived through interdependent variables. These equations on the one hand support hypothesis $\mathrm{H} 3$ conceptually and also help in deriving the framework for analysis on the other.

\section{Data and methodology}

The data on franchisees operating in the retail food sector have been collected from 236 outlets categorically falling into two categories including fast food retailing (144), frozen desserts comprising ice cream and yogurt products (92) distributed in three regions in Mexico City. The territorial distributions of sample franchisee outlets were earmarked in northern (Location 1), southern (Location 2) and downtown (Location 3) commercial areas in the city. Data have been collected on franchisee store basis that were purposively sampled by administering a semi-structured questionnaire. Data of 20 franchisee stores were omitted from the data analysis due to paucity of information. In all, 216 observations were used in the analysis, which contributed to a 91.52 per cent response rate in the study. The major questions administered to the franchisee outlet during data collection are exhibited in Appendix A.

All the franchisees were classified in the broad food products categories as mentioned above and the data on franchisee attributes were clustered on a monthly basis to facilitate temporal analysis for measuring franchisee performance. Accordingly, the data were spread over a 24-month period during 2004-2006. The relational and economic variables selected for the study are illustrated in Table 1.

Hypotheses have been tested using proxies for both market and aggregate demand and the log growth rate of retail sales derived from the annual reports of the franchisee companies covered under the study. Besides, the consumer price index available in the INEGI database for the reference period of study has been used as a proxy for market demand. The descriptive statistics of the variables selected for the study are shown in Table 2.

Table I: Variables chosen for the study

\begin{tabular}{|c|c|c|c|c|c|c|}
\hline \multicolumn{3}{|c|}{ Economic variables } & \multicolumn{3}{|l|}{ Relational variables } & \multirow{2}{*}{$\begin{array}{l}\text { Analytical } \\
\text { variables } \\
\text { Product-Market } \\
\text { Related }\end{array}$} \\
\hline Product based & Customer centered & Comparative & Technology related & Outlet based & Franchisee Image & \\
\hline EVSI & EVS2 & EVS3 & RVSI & RVS2 & RVS3 & AVSI \\
\hline Appearance & Telemarketing & Value for money & Innovativeness & Display & Reputation & Market demand $\left(P f_{t i}^{j}\right)$ \\
\hline Sensory & In-store service & Price sensitivity & Self-service & PoS support & Product line & $\begin{array}{l}\text { Aggregate demand } \\
\left(P f_{t i}^{m}\right)\end{array}$ \\
\hline Newness & Recreation & Profit margin & technology & Availability & Brands & $\begin{array}{l}\text { Sales in franchisee } \\
\text { retail stores }\left(N p s_{t i}^{j}\right)\end{array}$ \\
\hline Choice array & Leisure appeal & Services cost & Compatibility & Delivery & Loyalty & $\begin{array}{l}\text { Seasonality in sales } \\
\left(S n p_{t i}^{m}\right)\end{array}$ \\
\hline \multirow[t]{4}{*}{ Need } & Credit facilities & Promotion cost & Internet- & Responsiveness & Social image & \\
\hline & Customisation & Value additions & Connectivity & Prospecting & Referrals & \\
\hline & Take-away help & Competitiveness & Up-gradable & Sales volume & Advertising & \\
\hline & Car parking & Franchisor support & Value based & Alliance services & & \\
\hline
\end{tabular}

EVS: Economic variable segment; RVS: relational variable segment;AVS: analytical variable segment 
Table 2: Descriptive statistics for the selected variable segments for the study

\begin{tabular}{|c|c|c|c|c|c|c|c|c|c|c|}
\hline \multirow{2}{*}{$\begin{array}{l}\text { Variable } \\
\text { segment }\end{array}$} & \multicolumn{3}{|c|}{ Economic variables } & \multicolumn{3}{|c|}{ Relational variables } & \multicolumn{4}{|c|}{ Analytical variables } \\
\hline & EVSI & EVS2 & EVS3 & RVSI & RVS2 & RVS3 & $\left(P f_{t i}^{j}\right)$ & $\left(P f_{t i}^{m}\right)$ & $\left(N p s_{t i}^{j}\right)$ & $\left(S n p_{t i}{ }^{m}\right)$ \\
\hline Sample size & 216 & 216 & 216 & 216 & 216 & 216 & 216 & 216 & 216 & 216 \\
\hline Mean & 4.320 & 4.728 & 5.369 & 4.733 & 5.061 & 6.457 & 9.592 & 31.730 & 5.033 & 6.554 \\
\hline $\begin{array}{l}\text { Standard } \\
\text { deviation }\end{array}$ & 1.236 & 0.634 & 0.744 & 0.873 & 1.021 & 1.145 & 20.601 & 23.114 & 4.122 & 8.462 \\
\hline $\begin{array}{l}\text { Standard } \\
\text { error }\end{array}$ & 0.051 & 0.032 & 0.044 & 0.049 & 0.060 & 0.073 & 0.364 & 0.355 & 0.781 & 0.681 \\
\hline Skewness & -0.993 & -1.105 & $-1.25 \mid$ & -0.610 & -0.363 & 0.239 & 0.287 & -1.227 & -0.299 & -0.451 \\
\hline $\begin{array}{l}\text { Sample } \\
\text { variance }\end{array}$ & 1.061 & 0.534 & 0.659 & 0.783 & 1.514 & 1.399 & 0.876 & 1.025 & 0.402 & 0.391 \\
\hline
\end{tabular}

\section{FINDINGS AND DISCUSSION}

The results of the analysis of the selected variables as shown in Table 1 have been analysed towards measuring the performance of franchisee outlets that included demand for the products, price and promotional impact on customer satisfaction, volume of sales and seasonality factors affecting franchisee outlets. The results presented in Table 3 show that the strategic performance of franchisee outlets and effective retailing augment the customer perceptions and help build the long-run customer demand towards the franchisee outlets.

Analysis in the table reveals that customers derived higher perceived use value, competitive price tags and higher satisfaction in associating with franchisee outlets of established corporate brands in the food sector than going to low-profile brands' food outlets. Satisfaction over the franchisee outlets has been found to be higher in all locations covered under the study. Franchisee performance was reflected in their competitive gains, perceived use values, volume of buying and level of quintessence with the CRM services of the organisation. If these variables do not measure significantly, reversal of attitude among the customers may be emerging. The study, however, revealed that service-oriented sales strategies have helped in the franchisee outlets to enhance economic and relational performance, which appreciated the brand value in Mexican market. Hypothesis $\mathrm{H} 1$ is thus consistent with the results shown in Table 3 and stands established.

Seasonality in the sales of franchisee outlets and market demand has been analysed in reference to demand for products in the outlets, price, promotion, sales volume, market demand and in-store attractions offered to the customers. The growth rate of the aggregate demand has a positive and statistically significant impact on the introduction of new products in all five categories of products. The results are shown in Table 4.

In seasonal frequencies, a 5.92 per cent increase is found in the growth rate of aggregate demand in both categories of products on an average, which allows the performance of franchisee outlets to vary in the range 3.97-4.12 per cent. It has been observed that market demand has an important impact on the seasonality of sales that respond to price and promotion strategies of the franchisee outlets. The results also reveal that seasonality in market demand is also affected by the in-store attractions 
Table 3: Regression results of analysis of franchisee performance indicators $(n=216)$

\begin{tabular}{|c|c|c|c|c|c|c|c|}
\hline \multirow{3}{*}{$\begin{array}{l}\text { Performance } \\
\text { indicators }\end{array}$} & \multirow{3}{*}{$\begin{array}{l}\text { Measure } \\
\text { parameters }\end{array}$} & \multirow{3}{*}{$\begin{array}{l}\text { Value estimation parameters } \\
\text { for new products }\end{array}$} & Location I & Location 2 & Location 3 & \multirow[t]{3}{*}{$p$} & \multirow[t]{3}{*}{ Chi-square } \\
\hline & & & \multicolumn{3}{|c|}{ Franchisee outlets } & & \\
\hline & & & 65 & 78 & 73 & & \\
\hline \multirow[t]{4}{*}{ Functional } & $\left(P f_{t i}^{j}\right)$ & Product demand & $0.741^{*}$ & $0.722^{*}$ & $0.579 * *$ & $0.663^{* *}$ & 53.60 \\
\hline & $\left(P f_{t i}^{m}\right)$ & $\begin{array}{l}\text { Customer value appreciation in } \\
\text { eference price and promotion }\end{array}$ & $0.949 *$ & $0.866^{*}$ & $0.859 *$ & $0.562 * *$ & 59.12 \\
\hline & $\left(N p s_{t i}^{j}\right)$ & Volume of sales in franchisee outlets & $0.862 *$ & $0.715^{*}$ & $0.656^{* *}$ & $0.782 *$ & 84.22 \\
\hline & $\left(S n p_{t i}^{m}\right)$ & $\begin{array}{l}\text { Seasonality in sales observed in } \\
\text { franchisee outlets }\end{array}$ & $0.930 *$ & $0.748^{*}$ & $0.72 I^{*}$ & $0.694^{*}$ & 87.26 \\
\hline \multirow{2}{*}{$\begin{array}{l}\text { Constant } \\
\overline{\mathrm{R}}^{2}\end{array}$} & & & $0.349 *$ & $0.625^{*}$ & $0.428^{*}$ & & \\
\hline & & & $0.775^{*}$ & $0.858^{*}$ & $0.798^{*}$ & & \\
\hline
\end{tabular}

p-values: *significant at I per cent level, ${ }^{* *}$ significant at 10 per cent level

Table 4: Seasonality analysis of sales in franchisee outlets and market demand $(n=216)$

\begin{tabular}{|c|c|c|c|c|c|}
\hline \multirow{3}{*}{$\begin{array}{l}\text { Analytical } \\
\text { variables }\end{array}$} & \multicolumn{4}{|c|}{ Category of products in franchisee outlets and seasons } & \multirow{3}{*}{$\begin{array}{l}\text { Change factor } \\
\text { estimationa }(\lambda)\end{array}$} \\
\hline & \multicolumn{2}{|c|}{ Fast food products } & \multicolumn{2}{|c|}{ Frozen dessert } & \\
\hline & Peak season & Lean season & Peak season & Lean season & \\
\hline Product demand & $0.397^{*}$ & $0.538 *$ & $0.412 *$ & $(-) 0.366$ & $0.592^{*}$ \\
\hline Price & 0.215 & $0.646^{*}$ & $(-) 0.197$ & $(-) 0.143$ & $0.572 *$ \\
\hline Promotion & $0.311 * *$ & $0.420 *$ & $0.506 *$ & 0.192 & $0.433^{* *}$ \\
\hline Market demand & $0.543^{*}$ & $0.510 *$ & $0.497^{* *}$ & $(-) 0.106$ & $0.625^{*}$ \\
\hline Sales volume & $1.745^{*}$ & $0.926 *$ & $0.874^{*}$ & $0.544 * *$ & $0.936 *$ \\
\hline Store attractiveness & $1.430 *$ & $0.874 *$ & $0.86 I^{*}$ & $0.417^{* *}$ & $0.945^{*}$ \\
\hline Constant & $0.149 *$ & $0.625 *$ & $0.349 *$ & $0.079 *$ & 0.115 \\
\hline$\overline{\mathrm{R}}^{2}$ & $0.675^{*}$ & $0.558^{* * *}$ & $0.798^{*}$ & 0.341 & $0.664^{*}$ \\
\hline
\end{tabular}

p-values: *significant at I per cent level, **significant at I0 per cent level

aprofit of the franchisee outlets depends on the rate of fluctuation of volume of sales, price and demand for the products. The change factor $(\lambda)$ has been estimated through the equation $(\lambda)=\alpha+\sum_{i=1}{ }^{m} \hat{Z}\left[\partial_{v} / \partial_{s} \times \partial_{v /} \partial_{x} \times \partial_{v /} \partial_{p}\right]^{t}$ wherein change in total revenue, sales, demand and price are represented by $\partial_{v} \partial_{s}, \partial_{x}$ and $\partial_{p}$, respectively, in the given market $m$ and franchisee outlet $i$. In the above equation, $(\hat{Z})$ represents franchisee attributes and $(\alpha)$ is a constant.

and ergonomics of the outlets as it helps in driving consumer choice. Hence, hypothesis $\mathrm{H} 2$ is acceptable in view of the above interpretations of the results. The adjusted $\overline{\mathrm{R}}^{2}$ indicates that sales fluctuations explain 67.5 per cent for fast food products in the peak season and 55.8 during the lean season. In case of frozen food, fluctuation in the volume of sales has been found to be 79.8 per cent during the peak season and 34.1 per cent in the lean season. Thus, franchisee outlets should operate in synchronisation with market-demand expansions in order to capture the most sales possible during their short lifecycle. The empirical results indicate that the overall market demand both in reference to seasonal frequencies has a stronger impact on new product introductions than does market demand. For the first, the estimated coefficients pertaining to retail sales range between 0.417 and 1.745 , implying that retail sales tend to push 4.17 to a 17.45 per cent increase in overall performance in retailing 
food products at franchisee outlets. As market demand for fast food products is increasing in Mexico, the food products manufacturing companies take this opportunity to develop business-to-business negotiations. ${ }^{18}$ Hence, hypothesis $\mathrm{H} 2$ is further established by the data.

It has been observed during the study that performance drivers pertaining to competence in outlet management including supply, manufacturing, pricing and promotion strategy, in-store display and sales functions, customer services, technology and outlet ergonomics management govern the market leadership and the growth of the outlets influences aggregate demand for the products in the franchisee outlets. Similarly franchisee attributes comprising personalised customer relations, leisure support and customer convenience also play a significant role in enhancing the performance of the franchisee. Franchisee attributes were found to significantly influence the performance of Starbucks franchisee outlets during the study. The word of mouth, referrals and commercials issued by the franchisees drive the decision factors of customers' loyalty towards outlets and franchisee brands. The impact of franchisee attributes and the relationship with the parent company on the overall performance contributed by different variables is shown in Table 5 .

It may be observed from the results shown in the above table that the contribution of franchisee attributes to the overall performance of the outlets was 78.3-93.6 per cent in the various locations covered under the study, while performance drivers influenced 78.1-94.7 per cent overall performance of the franchisee outlets. The results shown in Table 5 also indicates that good retailing services $\left(Z_{x i}\right)$, coupled with a strong franchisor relationship $\left(F_{x}\right)$, help in extending support to the performance drivers $\left(V^{\prime}\right)$ and augmenting the aggregate demand $\left(X_{n}\right)$ for the products and services in the franchisee outlets. Accordingly, it may be stated that the results presented in the above table support hypothesis $\mathrm{H} 3$; hence it has been established.

Inference may also be drawn from the correlation matrix presented in Table 6 that the customer value in the franchisee outlets is largely enhanced by the point of sales promotions and in-store recreational facilities. In turn, augmented customer value helps in increasing the performance and growth of franchisee outlets.

Table 5: Impact of franchisee attributes and relationship with parent company on overall performance $(n=2 \mid 6)$

\begin{tabular}{|c|c|c|c|c|c|c|c|}
\hline \multirow[t]{3}{*}{ Variable segments } & \multirow{3}{*}{$\begin{array}{l}\text { Measure } \\
\text { parameters }\end{array}$} & \multirow{3}{*}{$\begin{array}{l}\text { Performance estimation } \\
\text { parameters }\end{array}$} & Location I & Location 2 & Location 3 & \multirow[t]{3}{*}{$p$} & \multirow[t]{3}{*}{ Chi-square } \\
\hline & & & \multicolumn{3}{|c|}{ Franchisee outlets } & & \\
\hline & & & 65 & 78 & 73 & & \\
\hline \multirow[t]{3}{*}{ Economic variables } & $(\hat{Z})$ & Franchisee attributes & $0.936^{*}$ & $0.783^{*}$ & $0.891 *$ & $0.44 I^{* *}$ & 54.72 \\
\hline & $\left(V^{\prime}\right)$ & Performance drivers & $0.947^{*}$ & $0.842^{*}$ & $0.78 I^{*}$ & $0.616 *$ & 59.22 \\
\hline & $\left(X_{n}\right)$ & Aggregate demand & $0.94 I^{*}$ & $0.732^{*}$ & $0.866^{*}$ & $0.648 *$ & 61.31 \\
\hline \multirow[t]{2}{*}{ Relational Variables } & $Z_{x i}$ & Customer services & $0.92 I^{*}$ & $0.736^{*}$ & $0.912^{*}$ & $0.592 * *$ & 64.21 \\
\hline & $F_{x}$ & Franchisor relationship & $0.943^{*}$ & $0.839 *$ & $0.911 *$ & $0.398 * *$ & 62.81 \\
\hline \multirow{2}{*}{$\begin{array}{l}\text { Constant } \\
\bar{R}^{2}\end{array}$} & & & $0.58 I^{*}$ & $0.725^{*}$ & $0.83 I^{*}$ & & \\
\hline & & & $0.722 *$ & $0.794^{*}$ & $0.81 I^{*}$ & & \\
\hline
\end{tabular}

p-values: *significant at I per cent level, **significant at 10 per cent level 
Table 6: Inter-group ${ }^{a}$ correlation matrices $(n=216)$

\begin{tabular}{|c|c|c|c|c|c|c|}
\hline Variable segments & $v_{1}$ & $v_{2}$ & $v_{3}$ & $V_{4}$ & $V_{5}$ & $v_{6}$ \\
\hline $\begin{array}{l}\text { Risk perceived by the franchisees for high } \\
\text { price }\left(V_{1}\right)\end{array}$ & 1.000 & & & & & \\
\hline Perceived brand value $\left(V_{2}\right)$ & $0.63 I^{*}$ & 1.000 & & & & \\
\hline Franchisee attributes $\left(V_{3}\right)$ & 0.371 & $0.694 *$ & 1.000 & & & \\
\hline Volume of sales $\left(V_{4}\right)$ & $0.827^{*}$ & 0.510 & $0.735^{*}$ & 1.000 & & \\
\hline Franchisee store attraction $\left(V_{5}\right)$ & 0.251 & 0.294 & 0.306 & $0.682 *$ & 1.000 & \\
\hline Availability of a wide range of products $\left(V_{6}\right)$ & $0.542^{* *}$ & $0.791 *$ & $0.728^{*}$ & $0.643 *$ & 0.475 & 1.000 \\
\hline Store loyalty among the customers $\left(V_{7}\right)$ & $0.573^{* *}$ & 0.451 & $0.915^{*}$ & $0.868^{*}$ & $0.822^{*}$ & $0.819 *$ \\
\hline
\end{tabular}

p-values: *significant at I per cent level, **significant at 10 per cent level

${ }^{a} \vee$ ariables are selected from the segments shown in Table I.

The results of the correlation matrix indicate that there exists a lower degree of correlation between the risk perceived by the franchisees for high price and perceived brand value $\left(V_{1}, V_{2}\right)$, application and franchisee attributes and perceived brand value $\left(V_{3}, V_{2}\right)$ and perceived risk of franchisees and franchisee attributes $\left(V_{1}, V_{3}\right)$. Similarly, the variable of franchisee outlet attraction and volume of sales $\left(V_{5}, V_{4}\right)$ franchisee outlet attraction and store loyalty $\left(V_{5}, V_{7}\right)$, and store loyalty and availability of wide range of products $\left(V_{7}, V_{6}\right)$ are also observed to have a correlation of a higher degree. It may be observed from the above matrix that the coefficient has a maximum value of 0.915 , which was significant for multiple co-linearity. The results of the correlation matrix also support hypotheses $\mathrm{H} 1$ and $\mathrm{H} 3$.

Finally, the results of data analysis may be summarised, indicating that the performance of a franchisee outlet depends on economic and relational variables and seasonal cycles are more regular than business cycles, and therefore their timing is much more predictable. Franchising companies synchronise the timing of launching their new products much more easily with the seasonal demand peaks. It may be seen from the above table that all hypotheses framed during the study were consistent with the results and were thus established. The model used in the study to analyse market demand and seasonality factors is also found to be consistent with the results that state that new product introductions follow seasonal patterns, set by Pashigian and Bowen ${ }^{35}$ and that seasonal patterns of retails sales influence introduction of new products into the market as dealt within the study conducted by Courty and $\mathrm{Li}^{36}$

\section{MANAGERIAL IMPLICATIONS}

Franchisors suggest that the biggest barrier to growth is a lack of suitable franchisees. One possible reason for the dearth of potential franchisees is the lack of public awareness of franchising and the opportunities it affords for both self-employment and small business development. Systematically explored concepts in the field of customer value and market-driven approach towards new products would be beneficial for a company to derive long-term profit optimisation strategy over the period. 
On a tactical level, managers need to consider the optimum spread of customers on a matrix of product attractiveness and market coverage. This needs careful attention and application of managerial judgment and experience to measure the customer-value-driven performance of the retail stores considering the innovative sales approaches for organic products, store layouts, product displays supported with comprehensive POS information, brand information and other loyalty parameters of the consumers. The success of franchisee outlets is derived through the impact of corporate environment and customer satisfaction as shown in Figure 1.

The convergence of three forces in franchising business consisting of customers, manufacturers and retailers has been explained in the figure, which illustrates that parent companies have the dual responsibility to cater information to customers and to provide competitive gains to the franchisees. The buying decision of customers largely depends on the franchisee environment wherein customers evaluate the level of satisfaction and generate customer-to-business pull, in case of satisfaction being significantly high. Such conditions would help franchisees and their parent company to explore the expansion of their business. Hence, it is necessary for the managers to understand that customer value is context dependent and there exists a whole value network to measure, not just a value chain. This value network will contain important entities far beyond the ones commonly taken into consideration in financial projections and business analyses. Appropriate promotional strategies considering the economic and relational variables discussed in the study may be developed by the managers on measuring the intensity of leisure shopping and the scope of expanding the tenure of leisure shopping in view of optimising customer values and profit of the firm. One of the most

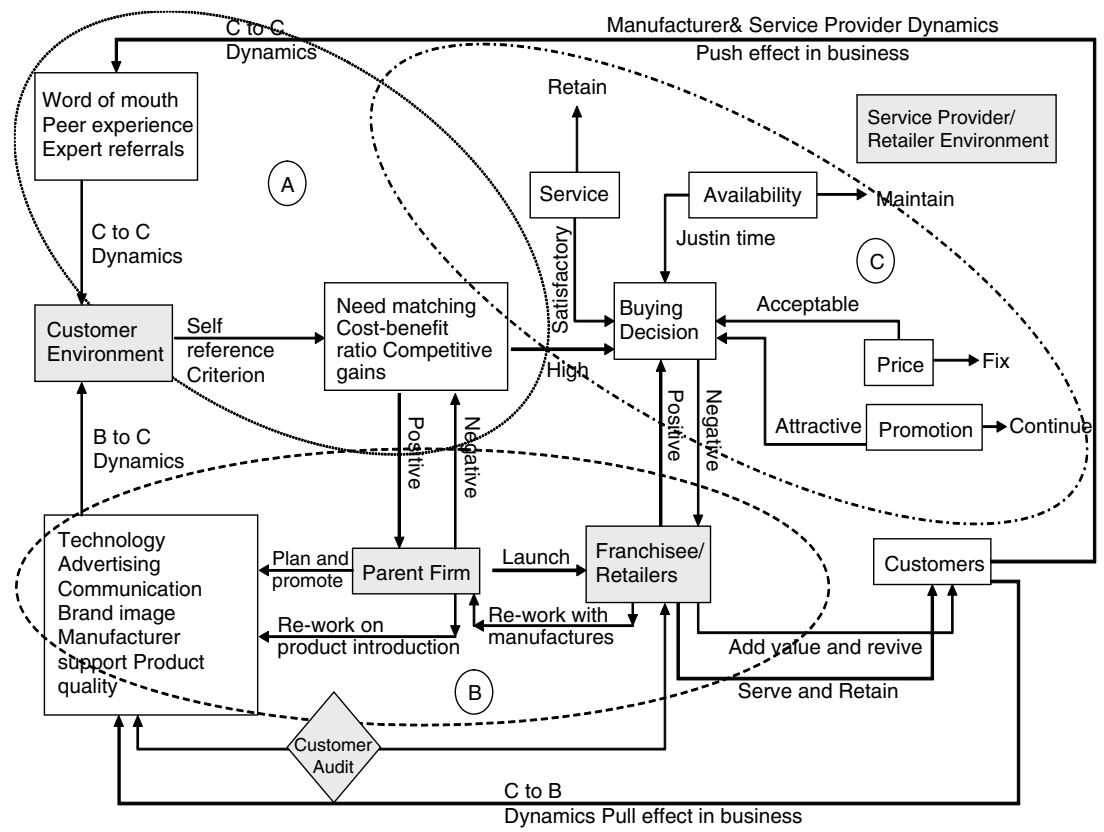

Figure I: Marketing dynamics and franchisee performance 
challenging aspects of franchising is finding the right people, and companies must be willing to devote significant time and resources to working closely with their product portfolios, if they wish to gain satisfactory value from their external business operations and investments.

\section{LIMITATIONS OF THE STUDY}

Like many other empirical studies, this research might also have some limitations in reference to sampling, data collection and generalisation of the findings. The samples drawn for the study may not be enough to generalise the study results. The questionnaires were translated into Spanish for the respondents in Mexico, which might have conveyed a varied conceptual sense to some extent. The open-ended questions were answered by the Mexican respondents in Spanish and some issues might have been overlooked in the transcription of the audio. To ensure, however, that the data cover a wider spatial and temporal dimensions in the study region, data should be cleansed and filtered with many variability factors affecting consumer behaviour and retailer performance.

\section{CONCLUSION}

This paper discusses the major factors affecting the performance of franchisees operating in the food sector. The major variables analysed in the study include recreational facilities, location of the store, shopping behaviour and store loyalty, product attributes and services, brand value, perceived values and price. It has been observed in the study that the performance of franchisee outlets depends on in-store attractions, supply and manufacturing management, quality, price and promotional strategies. Besides, relational variables including personalised customer services, leisure support and customer convenience also influence the performance of outlets. The degree of fit between a franchisor and franchisee relationship, however, also affects the performance of the outlets. In the long run, the success of franchisee outlets is associated with high levels of commitment, competitive skills and dynamics in functional management. Market demand and seasonality factors are important for driving the volume of sales in a given market. The study reviews existing theoretical and methodological issues and proposes a new model to measure the variability in market demand and seasonality factors for future research. Finally, there is a paucity of literature on this subject particularly in reference to Latin America. Hence, this paper attempts to contribute significantly to the existing studies.

\section{Acknowledgements}

I acknowledge the support provided by Amritanshu Rajagopal, undergraduate student of Industrial and Systems Engineering of ITESM, Mexico City Campus, in computing the data and developing the tables in this paper. 


\section{References}

1. Preble, J.F. \& Hoffman, R.C. (2006). Strategies for business format franchisors to expand into global markets. Journal of Marketing Channels. 13(3), 29-50.

2. Bradach, J.L. (1998). Franchise Organizations, Harvard Business School Press, Boston, MA.

3. Rudnick, L.G. (1984). An introduction to franchising, in Mendelsohn, M. (ed.), International Franchising: An Overview, Elsevier Science Publishers, B V Amsterdam, The Netherlands, pp. 11-63.

4. Altinay, L. \& Wang, C.L. (2007). The role of prior knowledge in international franchise partner recruitment. International Journal of Service Industry Management. 17(5), 430-443.

5. Doherty, A.M. \& Alexander, N. (2006). Power and control in international retail franchising. European Journal of Marketing. 40(11-12), 1292-1316.

6. Morschett, D., Swoboda, B. \& Foscht, T. (2005). Perception of store attributes and overall attitude towards grocery retailers: the role of shopping motives. The International Review of Retail, Distribution and Consumer Research. 15(4), 423-447.

7. Rajagopal (2006). Measuring customer value gaps: an empirical study in Mexican retail markets. Economic Issues. 11(1), 19-40.

8. Tikoo, S. (1996). Assessing the franchise option. Business Horizon. 39(3), 78-82.

9. Dant, R.P. \& Kaufmann, P.J. (2003). Structural and strategic dynamics in franchising. Journal of Retailing. 79, 263-275.

10. Wright, O., Frazer, L. \& Merrilees, B. (2007). McCafe: the McDonald's co-branding experience. The Journal of Brand Management. 14(6), 442-457.

11. Steinfield, F. (2004). The right data at the right fingertips. Harvard Management Update, Product \# U0401C, Harvard Business Online, 1-2.

12. Yap, K.B. \& Sweeney, J.C. (2007). Zone-of-tolerance moderates the service quality-outcome relationship. Journal of Services Marketing. 21(2), 137-148.

13. Paswan, A.K. \& Kantamneni, P.S. (2004). Public opinion and franchising in an emerging market. Asia Pacific Journal of Marketing and Logistics. 16(2), 46-61.

14. Salmi, L. \& Holmström, J. (2004). Monitoring new product introductions with sell-through data from channel partners. Supply Chain Management: An International Journal. 9(3), 209-212.

15. Ziamou, P. \& Veryzer, R.W. (2005). The influence of temporal distance on consumer preferences for technology-based innovations. Journal of Product Innovation Management. 22(4), 336-346.

16. Miranda, M., Konya, L. \& Havira, I. (2005). Shopper's satisfaction levels are not only the key to store loyalty. Marketing Intelligence and Planning. 23(2), 220-232.

17. Carpenter, J.M., Moore, M. \& Fairhurst, A.E. (2005). Consumer shopping value for retail brands. Journal of Fashion Marketing and Management. 9(1), 45-53.

18. Rajagopal (2006). Leisure shopping behavior and recreational retailing: a symbiotic analysis of marketplace strategy and consumer response. Journal of Hospitality and Leisure Marketing. 15(2), 5-31.

19. Bauer, H.H., Hammerschmidt, M. \& Staat, M. (2004). Analyzing Product Efficiency: A Customer Oriented Approach, University of Mannheim, February.

20. Steenkamp Jan-Benedict, E.M. \& Gielens, K. (2003). Consumers and market drivers of trial probability of new consumer packaged goods. Journal of Consumer Research. 30(3), 368-384.

21. Vázquez, L. (2005). Up-front franchise fees and ongoing variable payments as substitutes: an agency perspective. Review of Industrial Organization. 26(4), 445-460.

22. Monroy, M.F. \& Alzola, L.M. (2005). An analysis of quality management in franchise systems. European Journal of Marketing. 39(5-6), 585-605.

23. Hoffman, R.C. \& Preble, J.F. (2004). Global franchising: current status and future challenges. Journal of Services Marketing. 18(2), 101-113.

24. Paul, D. (2004). Maximizing productivity and capability: issues of professional development for franchisees. International Journal of Productivity and Performance Management. 53(4), 345-352.

25. Rajagopal \& Rajagopal, A. (2006). Trust and cross-cultural dissimilarities in corporate environment. Team Performance Management - An International Journal. 12(7-8), 237-252.

26. Sharif, K.J., Kalafatis, S.P. \& Samouel, P. (2005). Cognitive and behavioral determinants of trust in SMEs. Journal of Small Business and Enterprise Development. 22(3), 409-421.

27. Elie, O. \& Srinivasan, V. (2002). How much does the market value an improvement in a product attribute? Marketing Science. 21(4), 398-412.

28. Rajagopal (2006). Measuring customer value and market dynamics for new products of a firm: an analytical construct for gaining competitive advantage. Global Business and Economics Review. 8(3-4), 187-205. 
29. Calantone, R.J., Benedetto, C. \& Anthony, D. (2007). Clustering product launches by price and launch strategy. Journal of Business and Industrial Marketing. 22(1), 4-19.

30. Hahn, S. (2005). Pricing of a new product with consumer learning. International Economic Journal. 19(1), 37-49.

31. Parrish, E.D., Cassill, N.L. \& Oxenham, W. (2006). Niche market strategy for mature marketplace. Marketing Intelligence and Planning. 24(7), 694-707.

32. Lafferty, B.A. \& Goldsmith, R.E. (2004). How influential are corporate credibility and endorser attractiveness when innovators react to advertisement for a new high technology product? Corporate Reputation Review. 7(1), 24-26.

33. Rajagopal (2007). Buying decisions towards organic products: analysis of customer value and brand drivers. International Journal of Emerging Markets. 2(3), 236-251.

34. Han, S., Gupta, S. \& Lehmann, D.R. (2001). Consumer price sensitivity and price thresholds Journal of Retailing. 77(4), 435-456.

35. Pashigian, B.P. \& Bowen, B. (1991). Why are products sold on sales? Explanations on pricing regularities. Quarterly Journal of Economics. 106, 1015-1038.

36. Courty, O. \& Li, H. (1999). Timing of seasonal sales. Journal of Business. 72, 545-572.

\section{APPENDIX A}

\section{Principal questions administered to the respondents}

\section{Economic variables based}

1. What are the major economic variables that lead to the high performance of the franchisee outlets?

2. In your view, which factors influence sales, customer satisfaction and achieving returns?

3. Do you think that sustainable franchisee attributes such as personalised customer relations, leisure support and customer convenience ventures drive the performance of retail food outlets?

4. How do you describe the performance drivers for your franchisee outlet?

5. Do the competitive pricing and promotion strategies help to attract and retain customers?

6. How do outlet ergonomics and recreational retailing strategies help your outlet achieve higher performance?

7. In your view how do the introduction of new products affect the demand and sales in your outlets?

8. Describe the customer relationship practices of your franchisee outlet that lead to higher performance.

9. What should be the gestation period for your franchisee business to show-up positive financial results?

10. Which factors drive the seasonality for food products retailing at your outlet?

11. Are sales a major determinant in driving performance of your franchisee outlet?

12. How do you manage the drivers of performance indicated by you in one of the responses, to achieve higher performance and growth?

13. Whether any investment is made by the franchisor while initiating business at your outlet?

14. In you opinion, how high prices would react in sales and building brand value for various products available in your outlet? 
15. How do you develop customer value appreciation to augment demand for your products and positive response to the price and promotion strategies?

\section{Relational variables based}

1. Describe the workplace culture in your franchisee outlet.

2. Do you prefer to work individually or in team? Offer rationale for your answer.

3. Describe the process of developing marketing strategies for your franchisee outlet(s).

4. How effective is your relationship with the franchisor?

5 . What type of conflicts do you encounter in working with franchisor?

6. Describe your views on competitive marketing and sales strategies for higher performance and market leadership?

7. If you own this outlet independently without using franchisor's brand, how differently would you manage?

8. What are the major considerations that you make to be a franchisee?

9. Do you think it is good proposition to be proactive to the customers' needs for achieving higher loyalty effect?

10. In your view what is significance of cultural values in managing a franchisor-franchisee relationship successfully? 